\title{
RETHINKING THE LIMITS OF CLIMATE CHANGE ADAPTATION
}

Ma. Laurice Jamero, Miguel Esteban, Christopher Chadwick, and Motoharu Onuki

NO. 584

June 2019
ADB ECONOMICS WORKING PAPER SERIES 
ADB Economics Working Paper Series

\section{Rethinking the Limits of Climate Change Adaptation}

Ma. Laurice Jamero, Miguel Esteban, Christopher Chadwick, and Motoharu Onuki

No. 584 | June 2019
Ma. Laurice Jamero (laujamero@gmail.com) is Head of the Resilience Collaboratory, Manila Observatory, Ateneo de Manila University, Philippines. Miguel Esteban (esteban.fagan@gmail.com) is a professor in the Department of Civil and Environmental Engineering, Waseda University, Tokyo. Christopher Chadwick (c.j.chadwick@ljmu.ac.uk) is a professor at the Faculty of Arts Professional and Social Studies, Liverpool Screen School, Liverpool John Moores University, United Kingdom. Motoharu Onuki (onuki@edu.k.u-tokyo.ac.jp) is an associate professor of the Graduate Program in Sustainability Science - Global Leadership Initiative, The University of Tokyo, Japan.

The authors would like to thank Nicholson Tan of the Cebu Provincial Environment and Natural Resources Office for his technical assistance during our field surveys. We are also deeply grateful to the Municipal Government of Tubigon and the island communities of Batasan, Bilangbilangan, Pangapasan, and Ubay for their full cooperation in this research. This work was funded by the Program for Leading Graduate Schools, Japan Society for the Promotion of Science and Graduate Program in Sustainability Science - Global Leadership Initiative, Graduate School of Frontier Sciences, The University of Tokyo, Chiba, Japan. Also, a part of the present work was performed as one of the activities of the Research Institute of Sustainable Future Society, Waseda Research Institute for Science and Engineering, Waseda University. 
(C) 2019 Asian Development Bank 6 ADB Avenue, Mandaluyong City, 1550 Metro Manila, Philippines

Tel +632632 4444; Fax +6326362444

www.adb.org

Some rights reserved. Published in 2019.

ISSN 2313-6537 (print), 2313-6545 (electronic)

Publication Stock No. WPS190021-2

DOI: http://dx.doi.org/10.22617/WPS190021-2

The views expressed in this publication are those of the authors and do not necessarily reflect the views and policies of the Asian Development Bank (ADB) or its Board of Governors or the governments they represent.

ADB does not guarantee the accuracy of the data included in this publication and accepts no responsibility for any consequence of their use. The mention of specific companies or products of manufacturers does not imply that they are endorsed or recommended by ADB in preference to others of a similar nature that are not mentioned.

By making any designation of or reference to a particular territory or geographic area, or by using the term "country" in this document, $A D B$ does not intend to make any judgments as to the legal or other status of any territory or area.

This work is available under the Creative Commons Attribution 3.0 IGO license (CC BY 3.0 IGO)

https://creativecommons.org/licenses/by/3.o/igo/. By using the content of this publication, you agree to be bound by the terms of this license. For attribution, translations, adaptations, and permissions, please read the provisions and terms of use at https://www.adb.org/terms-use\#openaccess.

This CC license does not apply to non-ADB copyright materials in this publication. If the material is attributed to another source, please contact the copyright owner or publisher of that source for permission to reproduce it. $\mathrm{ADB}$ cannot be held liable for any claims that arise as a result of your use of the material.

Please contact pubsmarketing@adb.org if you have questions or comments with respect to content, or if you wish to obtain copyright permission for your intended use that does not fall within these terms, or for permission to use the ADB logo.

Corrigenda to ADB publications may be found at http://www.adb.org/publications/corrigenda.

Note:

In this publication, “\$” refers to United States dollars.

The ADB Economics Working Paper Series presents data, information, and/or findings from ongoing research and studies to encourage exchange of ideas and to elicit comment and feedback about development issues in Asia and the Pacific. Since papers in this series are intended for quick and easy dissemination, the content may or may not be fully edited and may later be modified for final publication. 


\section{CONTENTS}

TABLE, FIGURE, AND BOX

ABSTRACT

I. INTRODUCTION

II. METHODOLOGY 2

III. TIDAL FLOODING AND ADAPTATION IN TUBIGON 3

IV. $\quad$ EXPLORING THE LIMIT TO ADAPTATION

A. Physical or Biological Limit $\quad 6$

B. Cost of Adaptation $\quad 7$

C. Extreme Events 8

D. Development Challenges $\quad 8$

E. Future Outlook of Communities 8

$\begin{array}{llr}\text { V. CONCLUSION } & 9\end{array}$

REFERENCES 


\section{TABLE, FIGURE, AND BOX}

TABLE

Potential Limits of Adaptation

FIGURE

Typical Framing of Climate Change Adaptation

BOX

Problems with the Typical Framing of Climate Change Adaptation 


\begin{abstract}
Using a case study approach, this research explores the various potential limiting factors of climate change adaptation, based on the experience of four low-lying islands in central Philippines. In the aftermath of the 2013 7.2-magnitude Bohol earthquake, the islands now become flooded even during normal spring tides. Results show that, while development problems can constrain adaptive capacity against climate hazards, the outlook of the affected communities about their future on their home islands may ultimately determine the limits of adaptation. As social factors may play a greater role in adaptation than environmental factors, climate-smart development is needed, as well as proper education regarding climate risks and available adaptation options.
\end{abstract}

Keywords: agriculture, sampling methods

JEL code: Q00 


\section{INTRODUCTION}

According to the Intergovernmental Panel on Climate Change (IPCC) Fifth Assessment Report (AR5), global mean sea level is likely to increase between 26 centimeters $(\mathrm{cm})$ and $82 \mathrm{~cm}$ by the end of the 21st century (Church et al. 2013). Still, more recent work on probabilistic process-based models, which take into account rapid losses in the Antarctic ice sheets, put the potential for sea level rise (SLR) to an upper range of 2.97-3.39 meters for Representative Concentration Pathway 8.5 scenarios (Kopp et al. 2017; Le Bars, Drijfhout, and de Vries 2017). As emissions currently show no signs of abating despite the signing of the Paris Agreement in 2015, SLR could be well within the higher ranges of projections. Further, a special report published by the IPCC describing a $1.5^{\circ} \mathrm{C}$ warmer world indicates that more severe climate impacts may occur by the year 2040, unless significant and comprehensive actions to reduce emissions are taken by 2030 (IPCC 2018).

Aside from SLR, tropical cyclone intensification increases the risk of flooding in low-lying coastal communities (Nurse et al. 2014). Moreover, population increase and urbanization could lead to greater losses from climate impacts (Jongman, Ward, and Aerts 2012). With this, many existing studies suggest that climate change will inevitably lead to mass migration or the final abandonment of small low-lying islands (Myers 2002). In particular, it has been hypothesized that, in the long term, SLR coupled with mass coral mortality could render islands uninhabitable due to permanent inundation and land loss (Yamamoto and Esteban 2014). However, more recent studies claim that mass migration could happen even in the short term due to annual flooding, saltwater intrusion, and higher risk of storm surges, causing frequent damage to infrastructure, and disrupting food and water supply (Keener et al. 2013, Storlazzi et al. 2018).

Existing studies on mass migration typically frame adaptation to be a problem of tipping points (see Box on page 2), where in situ adaptation is often considered to be possible only up to a certain point, after which retreat becomes inevitable or even necessary (McLeman 2011, Barnett and O'Neill 2011).

\section{Typical Framing of Climate Change Adaptation}

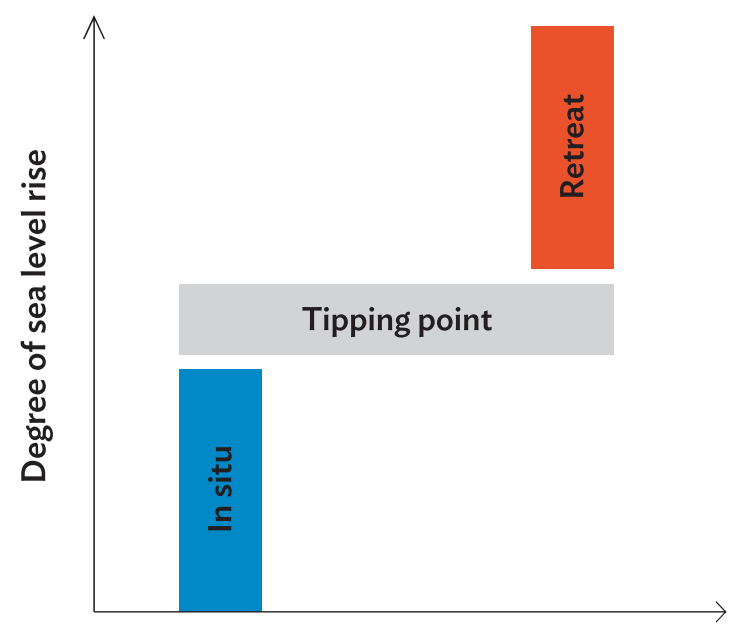

Adaptation

Note: In situ and retreat strategies are often portrayed to be mutually exclusive. Source: Authors. 


\title{
Problems with the Typical Framing of Climate Change Adaptation
}

\begin{abstract}
The typical adaptation framing, which portrays in situ and retreat strategies as being mutually exclusive, has at least two problems (see figure on page 1). First, tipping points are often expressed in terms of environmental factors, such as the degree of sea level rise (Nicholls and Cazenave 2010). However, an increasing number of studies indicate that social factors may play a greater role in the final decision to relocate (Perch-Nielsen, Bättig, and Imboden 2008; ArenstamGibbons and Nicholls 2006). Second, retreat strategies are shown to be a failure of in situ adaptation (Black et al. 2011). However, presenting these two main options as being mutually exclusive can inadvertently prevent communities from formulating a more integrated approach to climate change adaptation. Further, this false dilemma between retreat and in situ adaptation does not only oversimplify the problem of climate change (Nunn 2009), but also potentially leads to conflicting adaptation priorities and competition for limited financial resources.
\end{abstract}

Source: Authors.

This study aims to examine this typical framing of adaptation by exploring how the various potential limiting factors discussed in literature actually apply, or not apply, in the case of four low-lying island communities in central Philippines that currently experience the most extreme tidal flooding in modern history. By better understanding the factors that may play an important role in determining the limits of climate change adaptation, this study also hopes to elucidate the complex relationship between in situ and retreat strategies.

This paper is organized as follows. Section II describes the extreme case of tidal flooding in the islands of Tubigon, Bohol considered in this study. Section III outlines resulting problems and available strategies, and section IV discusses factors that could potentially limit adaptation. Section $V$ concludes with remarks on how to reframe our understanding of adaptation, and provides recommendations for future studies.

\section{METHODOLOGY}

On 15 October 2013, a 7.2-magnitude earthquake-induced land subsidence in four small island communities off the shore of Tubigon, Bohol (namely, Batasan, Ubay, Pangapasan, and Bilangbilangan) (see picture of the aerial view of Bilangbilangan island on page 3), causing them to now become inundated during high tides, especially during spring tides. The level of land subsidence and problems affecting these islands can be used as a proxy to understand how other low-lying islands around the world will adapt to SLR in the future, as they represent one of the most severe cases of tidal flooding in an island environment in modern history. In comparison, some atoll states currently experience severe inundation only about once a year, during king tides.

The four islands of Tubigon have very small land areas (between 1.5 hectares and 6 hectares only), with maximum elevations of about 2 meters above water (Jamero et al. 2017). They are densely populated, with each island having 60-250 households who mainly engage in small-scale fishing for livelihood (Jamero et al. 2018). The islands are impoverished, with the number of households with incomes below the income poverty threshold being significantly higher than the national average (Jamero et al. 2018).

This study uses a case study approach to examine the potential limits of adaptation. Drawing on the results of inundation surveys, site observations, and key informant interviews conducted by the authors from 2015 to 2018, the study compares the theoretical discussions on the limits of adaptation available in literature with the actual adaptation experiences of the island communities of Tubigon. 




Aerial view of Bilangbilangan island. Bilangbilangan becomes partially or completely inundated during normal spring tides, depending on local weather conditions (photo by Christopher Chadwick).

\section{TIDAL FLOODING AND ADAPTATION IN TUBIGON}

An inundation survey conducted by the authors in 2016 reveals that median flood heights in Batasan and Ubay islands measure up to about $40 \mathrm{~cm}$, while in Pangapasan and Bilangbilangan they are about $20 \mathrm{~cm}$ (Jamero et al. 2017). Three out of four islands were completely inundated, with only the school grounds (which also serve as an evacuation area) of Bilangbilangan being spared from the floods. Analyzing the observed flood threshold per island against the 2016 tidal calendar, the authors found that flooding could occur in Batasan and Ubay for up to 135 days, and in Pangapasan and Bilangbilangan for up to 44 days. Flooding on these days, which often occurs around the new and full moon phases of each month, may be partial or complete, depending on the actual tide level and local weather conditions.
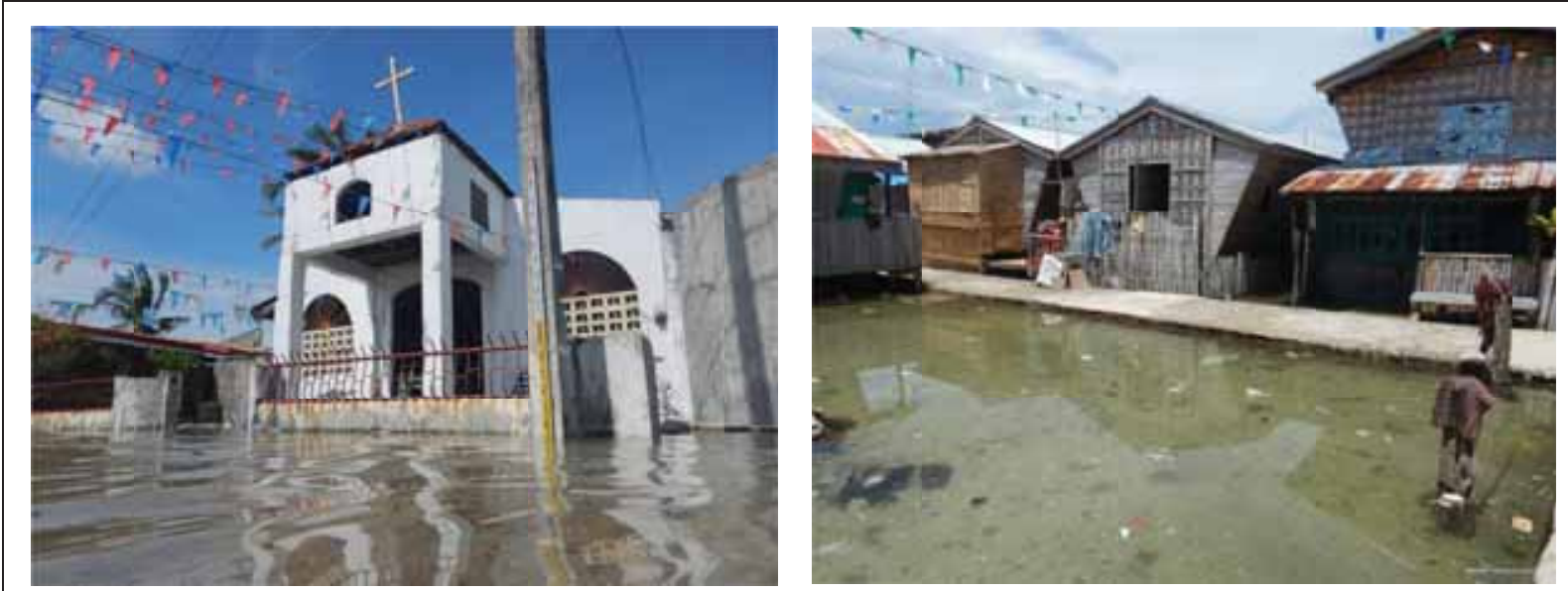

Tidal flooding and adaptation. Roads (right) and floors of important community services such as chapels (left) have been elevated in the islands of Tubigon (photos by Ma. Laurice Jamero). 
Frequent tidal flooding in the islands of Tubigon has led to a number of problems. For example, tidal flooding has left school children with no choice but to attend lessons even when classrooms are flooded and has posed serious health hazards as trash from households and human excreta from communal toilets feed into flood waters (Jamero et al. 2018). However, despite many challenges facing them, the islands continue to be inhabited. Instead, the residents have adapted to tidal flooding by raising the floor and ground of their houses and roads, building new houses on stilts, and improving protection from high waves by building revetments or planting mangroves (Jamero et al. 2017).

However, succeeding inundation surveys (conducted annually, around the king tide, since 2016) reveal that the situation of tidal flooding in the island communities in Tubigon may be getting worse. For example, the school grounds of Bilangbilangan island, which was spared from the floods in 2016, has already become inundated as well in 2018 (see picture on the right below). Interview with residents also indicate that the height of tidal flooding has been increasing each year across all islands.
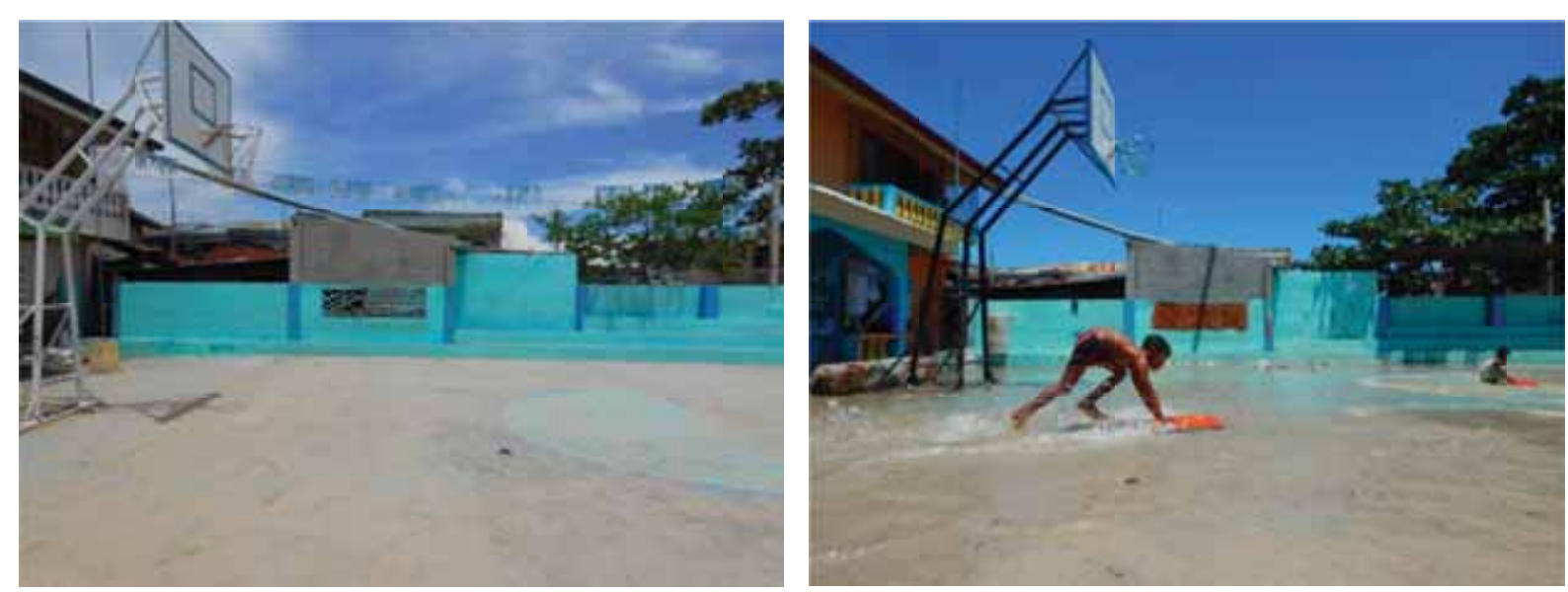

Bilangbilangan school grounds. During peak tides of +2.0 meters in June 2016 (left) and in June 2018 (right) (photos by Ma. Laurice Jamero).

In response to the worsening environmental conditions, the island communities of Tubigon and various supporting groups are reinforcing existing adaptation strategies, while exploring new ones. For example, a new project involving road elevation in Ubay island has ensured that new elevated roads are significantly higher than older ones, which were constructed and elevated immediately after the 2013 earthquake, to accommodate the increase in flood height. The Municipal Government of Tubigon has also become more proactive in helping the island communities properly implement in situ adaptation, such as by securing national funding for road elevation projects in the islands and by promoting the use of stones that have been sustainably sourced from the mainland in these projects in order to curb the impact of coral mining in the area (see picture on the right on page 5). Further, the municipal government has moved away from its initial traditional approach to relocation, which aims to move all residents of the islands into permanent houses in the mainland. Currently, the municipal government is promoting the use of education as a means to naturally depopulate the islands, by teaching school children skills and expertise that are employable in the mainland. 


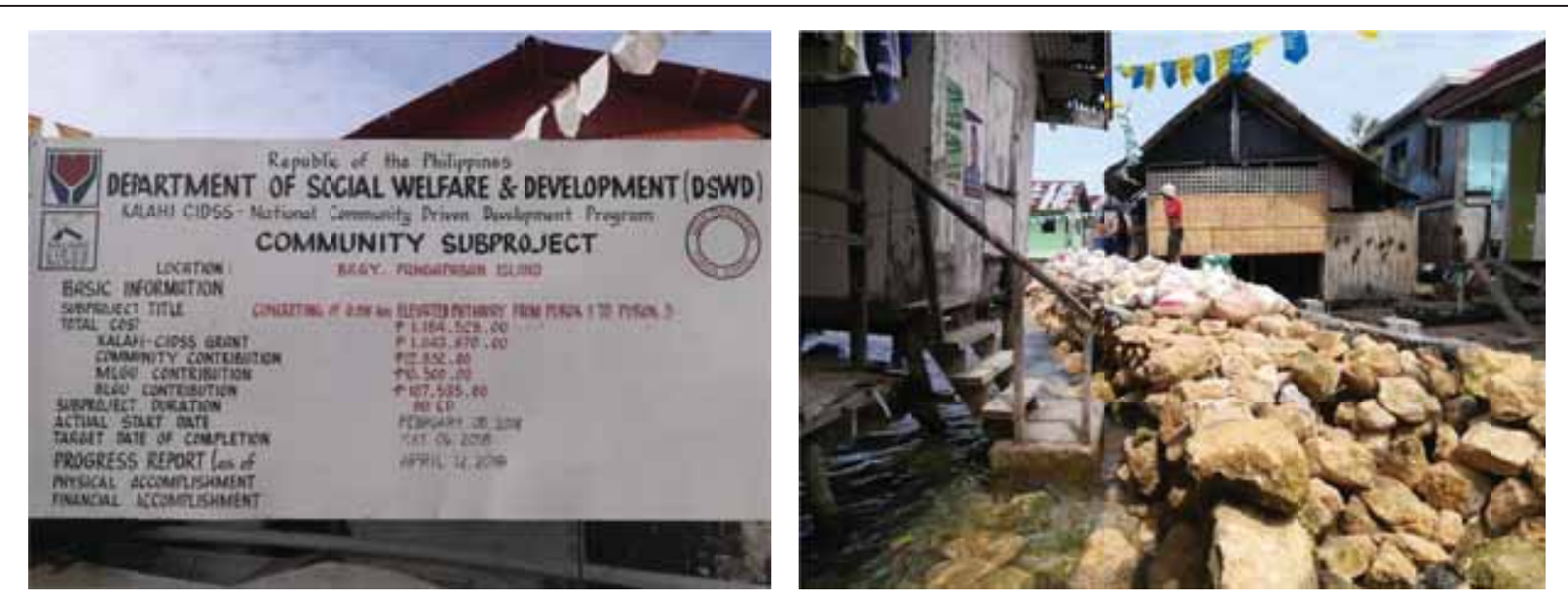

Road elevation project in Pangapasan. The project (left) used stones which are sustainably sourced from the mainland (right), rather than coral stones (photos by Miguel Esteban).

\section{EXPLORING THE LIMITS OF ADAPTATION}

Against the background of changing environmental conditions and evolving human strategies and approaches, the following section explores the various factors that could potentially limit adaptation (summarized in the table below).

\section{Potential Limits of Adaptation}

\begin{tabular}{lll}
\hline Potential Limiting Factors & Hypothesis from Existing Literature & Experiences of Islands of Tubigon \\
\hline Physical survival of the islands & $\begin{array}{l}\text { Islands will disappear, driving mass } \\
\text { migration in the long term. }\end{array}$ & $\begin{array}{l}\text { Islands remain inhabited despite severe, } \\
\text { frequent tidal flooding. }\end{array}$
\end{tabular}

Tidal flood height and frequency Tidal flooding will destroy agricultural land and freshwater sources, driving mass migration in the short term.

$\begin{array}{ll}\text { Cost of adaptation } & \text { Small island developing states are unable } \\ \text { to afford engineering solutions. }\end{array}$

Extreme events

Development problems

Development directly relates to adaptive capacity.

Climate change will increase disasters, driving mass migration in the short term.

When people lose faith in their own future on the islands, they migrate.
Severity of tidal flooding influences the level-not the limit_of adaptation.

Communities are able to adapt through basic technology and traditional knowledge.

There are changes in evacuation behavior and water collection practice, which are effective for predictable events such as typhoons and droughts.

Development problems, such as poverty and lack of livelihood options, are more pressing than tidal flooding.

Municipal government tries to create a positive outlook on life on the mainland through providing education.

Sources: Arenstam-Gibbons and Nicholls 2006; Fletcher and Richmond 2010; Keener et al. 2013; Nakamura et al. 2016; Smit et al. 2001; Storlazzi et al. 2018; Yamamoto and Esteban 2014. 


\section{A. Physical or Biological Limit}

The reefs around the islands are built by hard corals, and the islands themselves by the sediments that are produced when hard corals die. Thus, for islands to grow and continue to survive, it is important for corals to remain healthy (Yamamoto and Esteban 2014). However, a number of studies have highlighted the vulnerability of corals to climate change, particularly due to global warming and ocean acidification (Nurse et al. 2014). Following this logic, the very survival of islands is also threatened by climate change, as they face the double problem of SLR and the lack of sediment supply.

While several massive bleaching events have been documented in many places in recent times (Nurse et al. 2014), new studies are beginning to explore the feasibility of coral preservation and transplantation (Yamamoto and Esteban 2014). On the other hand, 4 decades' worth of remotely sensed data regarding the shoreline changes of all 101 islands of Tuvalu show a net increase in land area of the country as a whole, despite the fact that its local SLR was twice as much as the global average within that period (Kench, Ford, and Owen 2018). Similar results have been found by studies conducted in the 29 islands of Funafuti Atoll (Kench et al. 2015) as well as 12 different atolls in central and western Pacific (McLean and Kench 2015). Overall, these studies have found that, while some islands have decreased in size, many have also increased. This lack of uniformity in the islands' response to SLR reflects the highly dynamic nature of these systems, which continually adjust their size, shape, and position within the reef surfaces in response to various environmental changes (Kench et al. 2015). Ultimately, these findings challenge the notion that islands will become uninhabitable or even disappear in the face of SLR.

Confirming this point, the population of the island communities of Tubigon remain in their homes, despite coming face-to-face immediately after the earthquake with a degree of SLR not expected in other parts of the planet until the year 2100. Although the islands experience partial or complete flooding every spring tide, their daily lives have continued, with their social and cultural relations not appearing to have deteriorated. Thus, the height and even frequency of tidal flooding may not be sufficient for determining the limits of adaptation. To the contrary, the study found that these factors influence more significantly the level of adaptation, with island communities that are more severely affected also implementing adaptation measures more aggressively (Jamero et al. 2017).

The islands of Batasan and Ubay, which experience a higher degree of tidal flooding across more days within a given year, are widely investing in hard measures such as elevating floors and roads, and building stilted houses. On the other hand, Bilangbilangan and Pangapasan prefer soft measures, such as installing taller furniture at home and elevating personal belongings before tidal flooding. Rather than relocating, all of the islands have changed their evacuation behavior, relocating temporarily to the mainland in response not only to strong typhoons, but also to weak weather disturbances, whenever these coincide with high tides (Jamero et al. 2017).

However, as Batasan and Ubay (see picture on page 7), until recently, have been using coral stones as filling materials, examining the impact of rampant coral mining on the long-term physical viability of the islands is needed. A survey of a mined reef section in Batasan revealed a live hard coral cover of less than $10 \%$, with a further $30 \%$ of dead coral with algae, indicating that the area is already severely degraded (Jamero et al. 2017). 


\section{B. Cost of Adaptation}

In the existing literature, cost analysis has often been used as a means to understand a community's ability to adapt by comparing its financial resources with costs entailed by implementing various adaptation strategies (Nicholls and Tol 2006). In most cases, these studies find that small island developing states may be unable to afford engineering methods that tend to be very expensive (Yamamoto and Esteban 2014), hence rendering them vulnerable to climate change. However, as a glaring counterexample, the island communities of Tubigon have so far been able to adapt to tidal flooding despite their poverty and their use of basic technology (e.g., using local tidal information to determine the need for evacuation) or even traditional knowledge (e.g., building stilted houses, taller furniture). Thus, financial cost may not be enough to define the limits of adaptation, although the analysis of nonmonetary costs, such as social and cultural, may prove more meaningful.

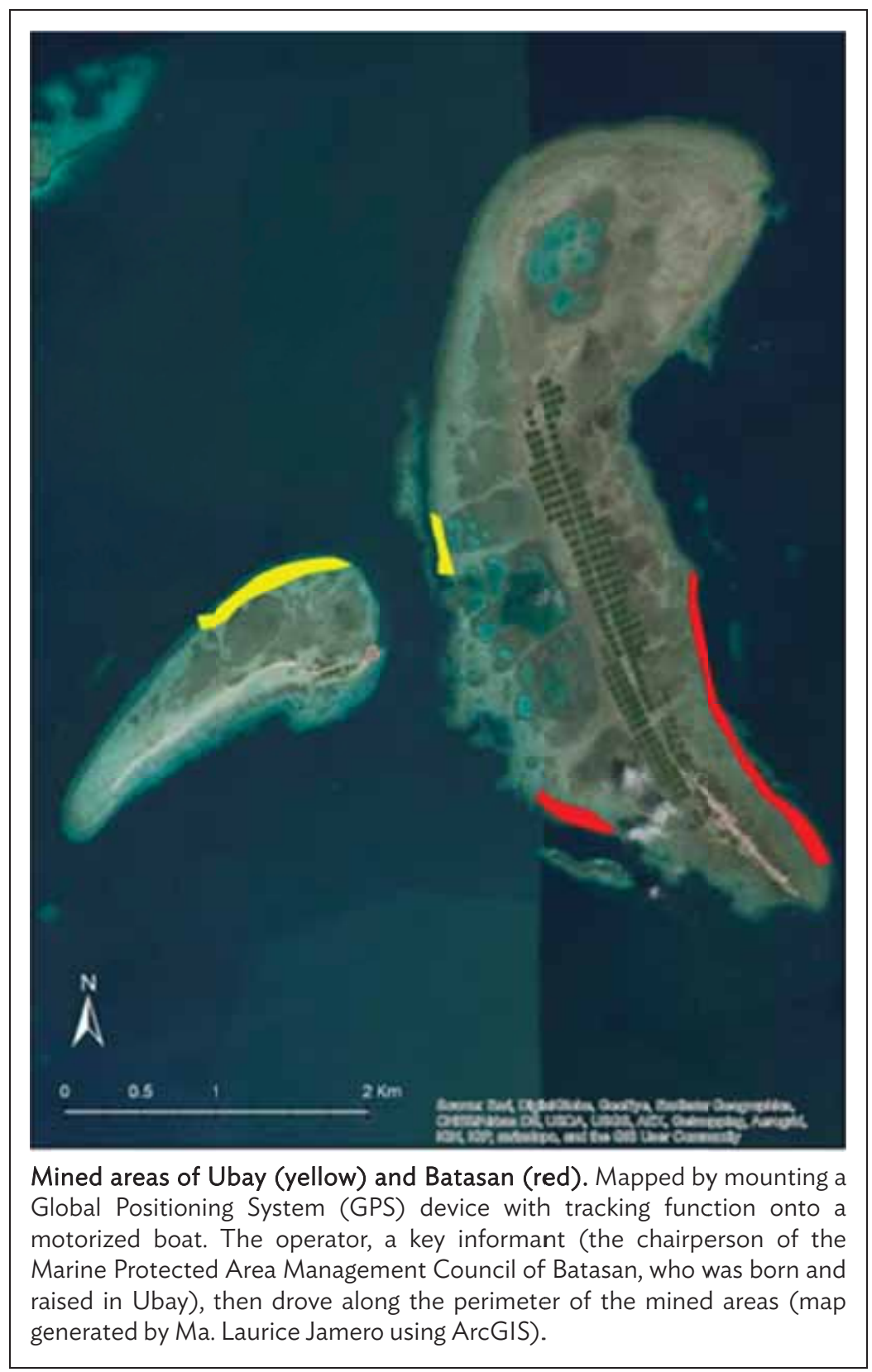




\section{Extreme Events}

Also, extreme events such as typhoons and droughts often are perceived to constitute a limit of adaptation, potentially driving mass migration even in the short term (Nakamura et al. 2016, Fletcher and Richmond 2010, Yamamoto and Esteban 2014). However, this study found that the island communities of Tubigon have remained in their homes despite experiencing several typhoons since the 2013 earthquake, and a 4-month long dry spell in 2016. Rather, they have adapted by changing their evacuation behavior and by acquiring more rainwater collectors or, at worst, importing water from the mainland (Jamero et al. 2018). Further, it can be argued that tidal flooding, which began immediately after earthquake-induced land subsidence, can also be considered an abrupt and extreme event. Still, the communities of Tubigon were able to adapt and continue to live on the islands. Overall, these experiences indicate that extreme events also may not be sufficient to breach the limits of adaptation. Although the impact of high-order extreme events (such as a category 4 or category 5 typhoon) remains to be seen, it is not clear whether this is possible in such sheltered areas of the Philippines.

\section{Development Challenges}

While the literature on climate change adaptation for small islands still focuses primarily on the physical hazards of climate change (Kelman 2014), the more established literature on disasters has already widely accepted that disaster risk is a function not only of physical hazards from the natural environment, but also of exposure and vulnerability due to human actions (Wisner et al. 2004). In other words, poor socioeconomic development can increase disaster risk by increasing the vulnerability of populations exposed to natural hazards.

Within the context of climate change, climate vulnerability has likewise been found to be mainly socioeconomic in nature (Nicholls and Tol 2006, Ayers and Forsyth 2009). Given this, the ability to adapt is also being related to the state of development (Smit et al. 2001). In simpler terms, as climate risks are driven by development-related challenges, climate change adaptation must therefore also focus on development. However, this point has not yet been sufficiently recognized in literature. Rather, by focusing primarily on quantifying climate hazards for small islands, many studies on adaptation have highlighted the need for mass migration instead of the need for development.

In line with this, the study found that the small problems that the island communities of Tubigon experience on a daily basis prove more critical. In particular, it is their persistent development problems such as poverty, limited infrastructure, and poor resource management that slowly erodes their capacity to adapt to slow onset environmental changes and extreme events in the long term. This affirms that social factors may have a greater influence on the limits of adaptation, rather than environmental factors alone.

\section{E. Future Outlook of Communities}

In Holland Island in Chesapeake Bay, US, where relative SLR accelerated in the mid-19th century, the community initially simply relocated to higher grounds within the island (Arenstam-Gibbons and Nicholls 2006). However, land appropriate for relocation eventually ran out, prompting some families to begin leaving the island. Finally, island abandonment was triggered when the remaining population fell below a level that could support the community. With the closure of important services such as schools, churches, and stores, what was left of the community lost faith in their own future on the island and migrated. 
This suggests that the future outlook of the communities themselves may ultimately determine the limits of adaptation. Thus, it is important to guide the communities in understanding fully and evaluating properly the climate risks that they are faced with, as well as the adaptation options that are available to them (including relocation), while giving them the space to contemplate their own future based on their own hopes and their existing social and cultural values.

However, the outlook of island communities does not necessarily have to be negative in order to prompt final abandonment. As envisioned by the Municipal Government of Tubigon, by providing better alternatives to the communities (i.e., potentially better opportunities as a skilled worker earning a stable income in the mainland), they may become inspired to start building their future elsewhere, triggering the natural depopulation of the islands.

\section{CONCLUSION}

While adaptation is typically understood to be a problem of environmental tipping points, this study highlights the need to reframe adaptation as a matter of choice, based on the affected population's outlook on their own future. At-risk communities should be able to decide for themselves the best way to adapt to climate change, given their own contexts and resources. However, to be able to make an informed choice, the communities need to have full awareness of the various adaptation options that are available to them, and a proper understanding of the risks involved in continuing to live on the islands, as well as in moving to other locations. Still, more importantly, the communities need to be empowered by promoting sustainable development as a means of building adaptive capacity.

With this, in situ strategies that address both the physical hazards posed by climate change and the socioeconomic drivers of vulnerability may be a good starting point for communities to adapt. In particular, in situ strategies should be able to address climate and disaster risks, while promoting socioeconomic development at the same time, so as to increase the overall adaptive capacity. In so doing, in situ strategies also can enable planned relocation, allowing island communities to move if, when, and where they choose to, avoiding the risk of sudden disaster-induced displacement, and minimizing the constraints posed by long-standing socioeconomic issues.

\section{Recommendations for Future Studies}

This study highlights the need to reconsider what it means for an island to become "uninhabitable" from both environmental and social perspectives. Based on examples from the Philippines, although environmental thresholds may already have been breached, communities were still able to continue to inhabit their islands. As discussed previously, the outlook of communities is important in determining whether the islands can still be deemed as capable of supporting their own future, and therefore remain habitable.

With few livelihood options, poor education, high poverty incidence, inadequate utilities and infrastructure, and small areas and populations, the island communities of Tubigon would normally be considered to have low adaptive capacities. Despite these constraints, community members and households were still able to implement a good number of adaptation strategies based on their own initiatives. This shows that island communities are far more resilient than otherwise assumed by the mass migration theory. Therefore, scientific experts and policy makers should consider also how to measure adaptive capacity more accurately in order to supplement it more effectively. 
Finally, future studies that identify more environment-sensitive strategies and investigate how existing maladaptive strategies may be corrected are also clearly needed to promote the long-term sustainability of coastal areas. While the level and limits of adaptation are potentially determined solely by the affected communities, scientists at least can provide support to understand and prevent maladaptation, and suggest appropriate adaptation strategies based on a given island's characteristics. Thus, this study highlights the need for greater financial and technical support from governments, nongovernment organizations, and academia, where self-managed efforts of island communities fall short. However, at the same time, it is important for these external agencies to view the island communities not only as beneficiaries, but rather as partners in increasing climate resilience. 


\section{REFERENCES}

Arenstam-Gibbons, Sheila J., and Robert J. Nicholls. 2006. "Island Abandonment and Sea-Level Rise: A Historical Analog from the Chesapeake Bay, USA.” Global Environmental Change 16 (1): 40-47.

Ayers, Jessica, and Tim Forsyth. 2009. "Community-Based Adaptation to Climate Change." Environment: Science and Policy for Sustainable Development 51 (4): 22-31.

Barnett, Jon, and Saffron J. O'Neill. 2011. "Islands, Resettlement and Adaptation." Nature Climate Change 2 (1): 8-10.

Black, Richard, Stephen R. G. Bennett, Sandy M. Thomas, and John R. Beddington. 2011. "Climate Change: Migration as Adaptation." Nature 478 (7370): 447-49.

Church, John A., Peter U. Clark, Anny Cazenave, Jonathan M. Gregory, Svetlana Jevrejeva, Anders Levermann, Mark A. Merrifield, Glenn A. Milne, R. Steven Nerem, Patrick D. Nunn, Antony J. Payne, W. Tad Pfeffer, Detlef Stammer, and Alakkat S. Unnikrishnan. 2013. "Sea Level Change." In Climate Change 2013: The Physical Science Basis. Contribution of Working Group I to the Fifth Assessment Report of the Intergovernmental Panel on Climate Change, edited by T. F. Stocker, D. Qin, G.-K. Plattner, M. Tignor, S. K. Allen, J. Boschung, A. Nauels, Y. Xia, V. Bex, and P. M. Midgley, 1137-216. Cambridge, UK and New York: Cambridge University Press. doi:10.1017/ CBO9781107415324.026.

Fletcher, Charles H., and Bruce M. Richmond. 2010. Climate Change in the Federated States of Micronesia: Food and Water Security, Climate Risk Management, and Adaptive Strategies. Hawaii: University of Hawaii, Sea Grant College Program.

Intergovernmental Panel on Climate Change (IPCC). 2018: "Summary for Policymakers." In Global Warming of $1.5^{\circ} \mathrm{C}$. An IPCC Special Report on the impacts of global warming of $1.5^{\circ} \mathrm{C}$ above pre-industrial levels and related global greenhouse gas emission pathways, in the context of strengthening the global response to the threat of climate change, sustainable development, and efforts to eradicate poverty, edited by V. Masson-Delmotte, P. Zhai, H. O. Pörtner, D. Roberts, J. Skea, P. R. Shukla, A. Pirani, W. Moufouma-Okia, C. Péan, R. Pidcock, S. Connors, J. B. R. Matthews, Y. Chen, X. Zhou, M. I. Gomis, E. Lonnoy, T. Maycock, M. Tignor, and T. Waterfield. Geneva, Switzerland: World Meteorological Organization.

Jamero, Ma. Laurice, Motoharu Onuki, Miguel Esteban, Xyza K. Billones-Sensano, Nicholson Tan, Angelie Nellas, Hiroshi Takagi, Nguyen Danh Thao, and Ven Paolo Valenzuela. 2017. "SmallIsland Communities in the Philippines Prefer Local Measures to Relocation in Response to Sea-Level Rise." Nature Climate Change 7 (8): 581-86.

Jamero, Ma. Laurice, Motoharu Onuki, Miguel Esteban, and Nicholson Tan. 2018. "Community-Based Adaptation in Low-Lying Islands in the Philippines: Challenges and Lessons Learned." Regional Environmental Change 18 (8): 2249-60. 
Jongman, Brenden, Philip J. Ward, and Jeroen C. J. H. Aerts. 2012. "Global Exposure to River and Coastal Flooding: Long Term Trends and Changes.” Global Environmental Change 22 (4): 823-35.

Keener, Victoria, John J. Marra, Melissa L. Finucane, Deanna Spooner, Margaret H. Smith, eds. 2013. Climate Change and Pacific Islands: Indicators and Impacts: Report for the 2012 Pacific Islands Regional Climate Assessment. Washington, DC: Island Press.

Kelman, Ilan. 2014. "No Change from Climate Change: Vulnerability and Small Island Developing States." The Geographical Journal 180 (2): 120-29.

Kench, Paul S., Murray R. Ford, and Susan D. Owen. 2018. "Patterns of Island Change and Persistence Offer Alternate Adaptation Pathways for Atoll Nations." Nature Communications 9 (1): 605.

Kench, Paul S., D. Thompson, Murray R. Ford, H. Ogawa, Roger F. McLean. 2015. "Coral Islands Defy Sea-Level Rise over the Past Century: Records from a Central Pacific Atoll." Geology 43 (6): 515-18.

Kopp, Robert E., Robert M. DeConto, Daniel A. Bader, Carling C. Hay, Radley M. Horton, Scott Kulp, Michael Oppenheimer, David Pollard, and Benjamin H. Strauss. 2017. "Evolving Understanding of Antarctic Ice-Sheet Physics and Ambiguity in Probabilistic Sea-Level Projections." Earth's Future 5 (12): 1217-33.

Le Bars, Dewi, Sybren Drijfhout, Hylke de Vries. 2017. "A High-End Sea Level Rise Probabilistic Projection including Rapid Antarctic Ice Sheet Mass Loss." Environmental Research Letters 12 (4). doi:10.1088/1748-9326/aa6512.

McLean, Roger, and Paul. Kench. 2015. "Destruction or Persistence of Coral Atoll Islands in the Face of 20th and 21st Century Sea-Level Rise?" Wiley Interdisciplinary Reviews: Climate Change 6 (5): 445-63.

McLeman, Robert A. 2011. "Settlement Abandonment in the Context of Global Environmental Change.” Global Environmental Change 21 (Supplement 1): S108-S120.

Myers, Norman. 2002. "Environmental Refugees: A Growing Phenomenon of the 21st Century." Philosophical Transactions of the Royal Society B: Biological Sciences 357 (1420): 609-13.

Nakamura, Ryota, Tomoya Shibayama, Miguel Esteban, and Takumu Iwamoto. 2016. "Future Typhoon and Storm Surges under Different Global Warming Scenarios: Case Study of Typhoon Haiyan (2013). Natural Hazards 82 (3): 1645-81.

Nicholls, Robert J., and Anny Cazenave. 2010. "Sea-Level Rise and Its Impact on Coastal Zones." Science 328 (5985): 1517-20.

Nicholls, Robert J., and Richard S. J. Tol. 2006. "Impacts and Responses to Sea-Level Rise: A Global Analysis of the SRES Scenarios over the Twenty-First Century." Philosophical Transactions of the Royal Society of London A: Mathematical, Physical and Engineering Sciences 364 (1841): 1073-95. 
Nunn, Patrick D. 2009. "Bridging the Gulf between Science and Society: Imperatives for Minimizing Societal Disruption from Climate Change in the Pacific." In Adaptation and Mitigation Strategies for Climate Change, 233-48. Tokyo: Springer.

Nurse, Leonard, Roger McLean, John Agard, Lino Pascal Briguglio, Virginie Duvat-Magnan, Netatua Pelesikoti, Emma Tompkins, and Arthur Webb. 2014. "Small Islands." In Climate Change 2014: Impacts, Adaptation, and Vulnerability. Part B: Regional Aspects. Contribution of Working Group II to the Fifth Assessment Report of the Intergovernmental Panel on Climate Change, edited by V. Barros, C. Field, D. Dokken, M. Mastrandrea, K. Mach, T. Bilir, M. Chatterjee, K. Ebi, Y. Estrada, R. Genova, B. Girma, E. Kissel, A. Levy, S. MacCracken, P. Mastrandrea, and L. White, 1613-54. Cambridge, UK and New York: Cambridge University Press.

Perch-Nielsen, Sabine L., Michèle B. Bättig, and Dieter Imboden. 2008. "Exploring the Link between Climate Change and Migration.” Climatic Change 91 (3-4): 375-93.

Smit, Barry, O. Pilifosova, I. Burton, B. Challenger, S. Huq, R. J. T. Klein, and G. Yohe. 2001. “Adaptation to Climate Change in the Context of Sustainable Development and Equity. In Climate Change 2001: Impacts, Adaptation, and Vulnerability. Contribution of Working Group II to the Third Assessment Report of the Intergovernmental Panel on Climate Change, edited by James J. McCarthy, Osvaldo F. Canziani, Neil A. Leary, David J. Dokken, and Kasey S. White, 879-906. Cambridge, UK: Cambridge University Press.

Storlazzi, Curt D., Stephen B. Gingerich, Ap van Dongeren, Olivia M. Cheriton, Peter W. Swarzenski, Ellen Quataert, Clifford I. Voss, Donald W. Field, Hariharasubramanian Annamalai, Greg A. Piniak, and Robert McCall. 2018. "Most Atolls Will Be Uninhabitable by the Mid-21st Century because of Sea-Level Rise Exacerbating Wave-Driven Flooding." Science Advances 4 (4): eaap 9741.

Wisner, Ben, Piers Blaikie, Terry Cannon, and lan Davis. 2004. At Risk: Natural Hazards, People's Vulnerability and Disasters (second edition). London and New York: Routledge.

Yamamoto, Lilian, and Miguel Esteban. 2014. Atoll Island States and International Law: Climate Change Displacement and Sovereignty. Berlin and Heidelberg: Springer-Verlag. 


\section{Rethinking the Limits of Climate Change Adaptation}

Sea level rise poses a serious threat to small island developing states. Although communities at risk are already implementing various strategies to address it, a lack of case studies prevents them from understanding the potential extent of adaptation. This paper tackles this gap by examining the case of low-lying islands in the Philippines that become flooded during spring tides as a result of earthquake-induced land subsidence. Its findings show that, while development problems constrain communities' adaptive capacity, people's outlook on their future may ultimately determine the limits of adaptation.

\section{About the Asian Development Bank}

ADB is committed to achieving a prosperous, inclusive, resilient, and sustainable Asia and the Pacific, while sustaining its efforts to eradicate extreme poverty. Established in 1966, it is owned by 68 members -49 from the region. Its main instruments for helping its developing member countries are policy dialogue, loans, equity investments, guarantees, grants, and technical assistance.

$\mathrm{ADB}$ 